\title{
Hallmarks of the Political in Community Organizing: An Arendtian Perspective
}

\author{
Paul Bunyan ${ }^{1}$ (D)
}

Accepted: 29 May 2021 / Published online: 22 June 2021

(C) The Author(s) 2021

\begin{abstract}
Drawing upon Hannah Arendt's adherence to existential phenomenology, the article advances a political understanding and interpretation of community organizing. Arendt, it is maintained, offers valuable insight into political phenomena which are constitutive of community organizing. Four aspects, in particular, are highlightedwhat I refer to as the four "A"s of association, action, appearance and authenticity—understood in existentialist, phenomenological, ontological and ultimately political terms, as primary ways of being-together-politically. The first part of the article examines Arendt's existential phenomenological approach in shaping her understanding of the political. This provides the theoretical basis for examining in the second part of the article, phenomena which are constitutive of community organizing, highlighting how association, action, appearance and authenticity form distinctive political characteristics of community organizing as an approach. At different points, brief reference is made to the work of London Citizens, the largest broadbased organization in the UK, in order to illustrate the connections between Arendtian thought and communitybased organizing.
\end{abstract}

Keywords Community organizing - Arendt . Phenomenology $\cdot$ Politics $\cdot$ The political

Paul Bunyan

paul.bunyan@edgehill.ac.uk

1 Department of Social Sciences, Edge Hill University, St Helen's Road, Ormskirk L39 4QP, Lancashire, UK

\section{Introduction}

In recent years, there has been growing interest in the thinking of Hannah Arendt and its relevance to understanding the nature of contemporary political life (Bernstein, 2018). In the field of community organizing specifically, there is a small but growing body of literature dedicated to a critical appraisal and application of Arendt's ideas on themes such as action, power and the nature of the political (Boyte, 2010; Bretherton, 2015; Bunyan, 2010, 2013; May, 2018). This article seeks to add to this literature. It is posited that in applying an Arendtian lens from an existentialist phenomenological perspective, significant insight is afforded into, amongst other things, the meaning and political nature of community organizing, the intersubjective and relational basis of the approach and into phenomena which are constitutive of human agency and "the political", more generally.

In setting out Arendt's significance to an understanding of the political nature of community organizing, the first part of the article examines Arendt's existentialist phenomenological approach in shaping her understanding of the political. The "political difference"-the distinction between "politics" and "the political" - employed in postfoundational thought, is posited as an important starting point for thinking about the nature of the political in relation to community organizing. Arising from this distinction, two concepts, shaped by Arendt's phenomenological interpretation of "the political", are examined; first, the notion of the associative political, recognized in postfoundational thought as the Arendtian trait (Marchart, 2007); and second Arendt's notion of plurality as the basis of political intersubjectivity (Loidolt, 2018). This provides the theoretical basis for examining in the second part of the article, phenomena (the four "A"s) which are constitutive 
of community organizing, highlighting how association, action, appearance and authenticity as ways of Being-together-politically, form the distinctive political basis and character of community organizing as an approach. The main aim in the article is to provide a theoretical perspective on community organizing but at different points brief reference is made to the work of London Citizens, the largest broad-based organization in the UK, in order to illustrate the connections between Arendtian thought and community-based organizing.

There are many variations of community organizing but in the context of this article it refers essentially to the approach pioneered by Saul Alinsky in the USA in the 1940s aimed at building political agency and redefining relationships of power within society. For over three decades from the 1940s, Alinsky built a reputation as one of America's most controversial and radical organizers, credited with changing urban politics and influencing future leaders, including President Barack Obama and Hillary Clinton. In the 1940s Alinsky established the Industrial Areas Foundation (IAF) to promote community organizing across the USA. The IAF remains today at the forefront of community organizing, working in more than 60 cities across the USA and with affiliates in Australia, Canada, Germany and the UK. To avoid repetition the term "community organizing" will for the most part be abbreviated to $\mathrm{CO}$ for the remainder of the article.

\section{Arendt and the Existential Phenomenological Tradition}

Arendt referred to herself as a political theorist and for much of her academic life rejected the term philosopher. Her unease towards philosophy stemmed from both her personal experience as a Jew and her scholarly activity as a philosophy graduate in Germany in the 1920s and 1930s. Arendt couldn't fathom how some members of the German academy, at the forefront of the philosophical world, failed to recognize and criticize the atrocities of National Socialism. Most notable amongst these was Martin Heidegger, her former teacher and lover. Seeing the " "professional thinkers' get lost in the ivory tower of thought, while the world was falling apart politically" (Fry, 2009:35), created in Arendt a deep frustration with traditional philosophy. The contrast between philosophy, the vita contemplativa, and politics, the vita activa, was to constitute a central and recurring theme throughout Arendt's work and scholarly career (Dolan, 2000).

Despite her frustration, Arendt was greatly influenced by the German philosophical tradition, particularly in its existentialist and phenomenological forms. Existentialism is a philosophical and literary movement that came to prominence in Europe in the mid-twentieth century, most closely associated with the philosopher Jean-Paul Sartre. The movement's antecedents, however, go back to the nineteenth and early twentieth century, influenced by the ideas of, amongst others, Kierkegaard, Nietzsche, Husserl and Heidegger, albeit the term "existentialism" itself was not used by any of these philosophers. As the name suggests, existentialism is concerned with fundamental themes and aspects of human existence, including, amongst other things freedom, death, finitude and authenticity (Reynolds, 2006). Arendt's particular existential interest lay in interpreting the meaning of plurality as a human phenomenon and how this informed understanding of the nature of the political.

The term "existential phenomenology" highlights the indebtedness of the so-called existentialist philosophers to the phenomenological project started by Edmund Husserl in the early twentieth century. In broad terms, phenomenology is an interpretive research approach which emerged out of a reaction to positivism. According to Willis (2001:3), it sought to steer a middle path "between objectifying views that posit that the world, as we know it, exists 'out there' independently of human consciousness: and mentalist views, that think the world is purely a construction of the mind". Originally devised by Husserl, the notion of going "back to the things themselves" allowed philosophers to suspend theoretical judgement about questions of the nature of reality to focus on how phenomena essentially appear and are experienced - the Greek meaning for phenomenon (phainomenon) is "that which appears". In addition, Husserl's approach "elevated the phenomena of everyday life (what he later called Lebenswelt-the lifeworld) to the same dignity, as matters for rigorous study, which Kant had bestowed only on the objects of natural science" (Hinchman \& Hinchman, 1984:188). Martin Heidegger was initially a student of Husserl and later his assistant at Freiburg University. Whilst very much influenced by Husserl, Heidegger took phenomenology in a different direction, arguing that through its focus on essential structures of consciousness, Husserlian phenomenology risked inadvertently reinforcing Cartesian mind-body dualism. Heidegger thus advocated the basis of his own phenomenology as one of interpretation of experience and explication of the meaning of being.

Despite their differences, Arendt was greatly influenced by the thinking of Heidegger and his "phenomenology of being". She is regarded as one of a number of "secondgeneration phenomenologists", including Sartre, MerleauPonty and Levinas, who developed their own approaches by critically working through the "first-generation phenomenologists", Husserl and Heidegger. According to Parekh (1981), one of the main objectives of The Human 
Condition, regarded by many as Arendt's magnus opus, was to provide a more satisfactory phenomenology of the human activities that are relevant to politics. In this respect, she is credited with the politicization of Heideggers' thought (Marchart, 2007). Adopting a phenomenological method, Arendt sought to uncover and "make available the objective structures and characteristics of political beingin-the-world as distinct from other forms of experience" (Yar, 2000:20).

\section{Post-foundationalism and the "Political Difference"}

In his quest to put being at the heart of philosophical inquiry, Heidegger in "Being and Time" distinguishes between the ontic level of beings as entities and the ontological level of being, understood as the fundamental structures of human existence (Heidegger, 2010). In philosophical thought, this is referred to as the ontological difference and it is from this that post-foundational political thought and the political difference is derived. Adherents of post-foundational thinking essentially contest the premise that there is an ultimate foundation upon which society and/or politics can be grounded. The notion of foundations is not rejected outright (that would represent an antifoundationalist perspective), rather, in rejecting an ultimate foundation, post-foundationalists ascribe to the notion of contingent grounds in the plural. For political theorists, such as Ernesto Laclau and Chantal Mouffe such a perspective formed the basis of their shift from an essentialist Marxist position grounded in economic determinism (and thus denying the autonomy of the political), to an understanding of social change and radical democracy as being contingent and best conceived in terms of a plurality of struggles: "The multiplication of political spaces and the preventing of power in one point are then preconditions of every truly democratic transformation of society" (Laclau $\&$ Mouffe, 2001:178). The idea of the absence of an ultimate foundation upon which society and/or politics can be grounded created a lacuna in terms of theorizing social and political change within a post-foundationalist framework and it was the political difference, mirroring Heidegger's ontological difference, which served to address this gap. Of the political difference, Marchart (2007:5) says:

As difference, this difference presents nothing other than a paradigmatic split in the traditional idea of politics, where a new term (the political) had to be introduced in order to point at society's 'ontological' dimension, the dimension of the institution of society, while politics was kept as the term for the 'ontic' practices of conventional politics (the plural, particular and, eventually, unsuccessful attempts at grounding society).
Arendt, along with the political theorist Carl Schmitt, are recognized as two of the pre-eminent theorists of the nature of the political. For Arendt, it is the free association of people in their plurality which brings the political into being. For Carl Schmitt, it is an outside enemy or antagonism which is constitutive of the political. On the distinction between the Arendtian and Schmittian perspectives, Marchart (2007:40) says,

...the associative trait of the political is not meant to indicate merely the phenomenon of political collectivity (all politics is collective), but the way in which the collective is established. This is where the main difference lies: seen from an Arendtian angle, people in their plurality freely associate within the public realm by their care for the common. Seen from a Schmittian angle, though, a collectivity is established through an external antagonism vis-à-vis an enemy or constitutive outside, that is, by way of dissociation.

From an Arendtian perspective, it is not just that people associate freely that constitutes the mark of the political but crucially that this takes place across a plurality of beliefs and perspectives. It is through this process that a public realm, forever contingent, is constituted. Central therefore, to Arendt's conceptualization of the associative political is this notion of "plurality" and it is her phenomenological understanding of it as the foundation of the political to which I now turn.

\section{Plurality as the Foundation of "The Political"}

According to Canovan (1992), Arendt's inquiry into the nature of the political as a force for good was driven by her experiences of totalitarianism, elucidated in her first book On the Origins of Totalitarianism. Against a deterministic totalitarianism underscored by the hubristic notion that "everything is possible", is set an understanding of human freedom which is more contingent, spontaneous, plural and limited. It is through constant reflection and attention to plurality as a phenomenon that Arendt's understanding of the nature of the political is grounded and developed. In her book entitled "Phenomenology of Plurality: Hannah Arendt on Political Intersubjectivity", Sophie Loidolt provides a detailed interpretation and analysis of the phenomenological approach adopted by Arendt. Loidolt's phenomenological understanding adds a new layer and depth of interpretation to Arendt's perspective on plurality. According to Loidolt (2018:2),

....one can gain a full understanding of the nature and transformative force of plurality only if one conceives of it in a phenomenological context. Plurality is not something that simply is, but essentially 
something that we have to take up and do. Therefore, it manifests itself only as an actualization of plurality in a space of appearances.

Plurality therefore is understood not just as a statement of fact in terms of numbers, it is also crucially an intersubjective phenomenon which is actualized in the interplay of multiple perspectives. There are a number of interconnected ideas and concepts which flow from this phenomenological conception of plurality. First, plurality and human action are inextricably linked as the foundation of Arendt's conception of the political. In her analysis of the vita activa or active life in The Human Condition, Arendt makes a distinction between action, on the one hand and labour and work, on the other. It is beyond the scope of this article to look in detail at the distinction between each of these human activities, but essentially Arendt argues that action constitutes the most important category of human activity because it is through action that the equality, uniqueness and difference of each human being have the potential to be realized. It is in making oneself known, both individually and collectively, through words and deeds in the presence of others, that new beginnings, initiatives and capacities for freedom are made possible. Arendt refers to the phenomenon of natality, the birth of every individual, as being the basis of this promise and potential of a new beginning.

Second, and following on from the first point, Arendt conceives of power as the capacity to act in concert. Power is understood as a human creation, a collective achievement, brought about through the joining together of a plurality of actors for a common political purpose (Passerin, 1994). For Arendt power is ".... the 'we' that emerges from a constant readiness to act together, rising from an intense mode of communication and directedness at each other's actions .......its unity is constituted through ongoing personal interaction and attention" (Loidolt, 2018:226). This conception of power is very different to what Arendt referred to as the command-obedience model, which "equates power with the rule of law and presupposes that the paradigmatic power relation is that by which a sovereign imposes his will on his subjects" (Allen, 2002:132).

Third, it is the capacity to act in concert that "keeps the public realm, the potential space of appearance between acting and speaking men, in existence" (Arendt, 1998:179). In terms of Arendt's phenomenological methodology, the concept of "appearance" is highly significant. In the Human Condition, she says "For us, appearance-something that is being seen and heard by others as well as by ourselves-constitutes reality" (Arendt, 1998:50). For Arendt, therefore, reality is constituted through pluralized appearance and this is most marked in action with others through the activity of speech and deeds. This is what constitutes the potential space of appearance or public realm between people. Such spaces of appearance, Arendt maintains, are not permanent, but are continually created and recreated by action.

Finally, in her phenomenological analysis of actualized plurality, Loidolt (2018:154) highlights the "irreducible uniqueness of each person in the mode of togetherness". Loidolt's claim is that Arendt's conception of plurality insists upon the individual finding meaning through action with others. Loidolt (2018:155) says,

A phenomenology of plurality does not aim at a neutral description of all possible forms of collectivity but focuses instead on the fact that being plural is something that must explicitly be realized and defended against all other forms of collectivity that swallow individuality.

This is an important aspect which is often overlooked in discussion about collective action. It emphasizes the Kantian notion of the importance of human beings being treated as ends in themselves, rather than means to achieving a particular end. It is particularly relevant to $\mathrm{CO}$ where tensions can sometimes exist between achieving a balance between action, so that it is not simply seen as an end in itself, and investing sufficient time in developing the relational culture which will help sustain the organization over time and enable people to find meaning in their individual and collective involvement.

In concluding the first part of the article, the "political difference" and the notion of plurality provide important reference points for thinking about the role of civil society in advancing a radical understanding of democratic politics and of the distinctive political nature and character of community organizing in contributing towards this. Civil society in its plurality and diversity has a critical role to play in ensuring that the contingency and groundlessness of the political acts as a necessary counterpoint to the tendency in politics for over-determination based upon an understanding of "the premise of society as a sutured and self-defined totality"(Laclau \& Mouffe, 2001:111). The two realms of "politics" and "the political" are not mutually exclusive but inextricably linked. It is not that the political represents a separate, purer or superior realm to politics, because in and of itself the political cannot exist outside of the necessary, momentary and contingent groundings that politics generates. Rather, the political as ontological, which as Heidegger posits never appears as such, can be understood "as the grounding and instituting moment of the social, constantly searching for its ontic actualization via politics" (Marchart, 2011:966). For Marchart, the implications of the political difference in relation to democracy and democratic theory lie in the way 
that different regimes react to what he refers to as the "irresolvable contingency of social affairs". Marchart (2011:967-968) says:

While in some the absence of an ultimate ground of the social is negated, repressed, or disavowed, in democracy this absence is institutionally accepted, even promoted........For this reason it makes sense to define as democratic those symbolic arrangements of a given society that help to accept the ultimate failure of any attempt at grounding this very society, thus bringing to presence the very absence of an ultimate ground. Democracy openly turns the failure of foundation - which in other regimes may remain a hidden, dirty secret - into its very own ground.

Radical democratic politics is thus borne out of the constant interplay of "politics" and "the political" and the contingent foundations that emerge from this interaction. Community organizing as a civil society-led strategy, provides an important means through which the interplay of "politics" and "the political" is brought into sharp relief. In the second part of the article, the methodology and ontology of community organizing as an expression of the political are discussed, focusing on four phenomenathe four "A"s of association, action, appearance and authenticity.

\section{Hallmarks of the Political in Community Organizing}

As mentioned in the introduction $\mathrm{CO}$ represents a distinctive civil society-led approach to building political agency and contesting relations of power within society. As such the approach has been understood and critiqued from a number of different perspectives both conceptually and politically. For example, on the left, theories of mobilization associated with social movements have been applied (Fisher \& Kling, 1994; DeFilippis et al., 2010), as well as concepts such as hegemony (Beck \& Purcell, 2013), in critically examining the strengths and limitations of $\mathrm{CO}$ and the role of civil society in both maintaining but also potentially contesting relations of power in society. On the right, $\mathrm{CO}$ has been framed in terms of voluntarism and civic duty. In the UK, such a perspective formed the basis of David Cameron's "Big Society" agenda, instituted as part of the 2010 Coalition government's political programme and which included an undertaking to train and deploy 5000 community organizers to "empower" local communities.

Between more radical notions of contesting relations of power in society, to more conservative ideas associated with civic duty and so-called empowerment, $\mathrm{CO}$ has found resonance across the political spectrum (Fisher \& Dimberg, 2016). This broad appeal can be regarded as a strength; however, it can also render somewhat problematic the theoretical and political basis of the approach. An existential phenomenological perspective, based in Arendtian post-foundational thinking and starting with the so-called political difference, provides an alternative understanding of the distinctive political nature of CO. In what follows, Arendt's phenomenological understanding of the political and how it is constituted will inform an analysis of four key features or phenomena of $\mathrm{CO}$, what I term the four "A"s of association, action, appearance and authenticity. In existentialist and phenomenological terms, each of these features represents the subjective, intersubjective and relational basis of $\mathrm{CO}$ through which meaning is found in being-together politically.

\section{Association}

Association as a concept has been central to democratic theory from Alexis De Tocqueville in the nineteenth century to Robert Putnam in more recent decades. In his theorization of the associational terrain, Warren (2001) draws attention to the democratic effects of what De Tocqueville referred to as secondary associations, in enabling people to move out from their primary associations, i.e. their families and households, to relate with, act and develop a sense of interdependence with others. In this way, Warren (2001:30) says,

"associations provoke a civic consciousness and displace narrow self-interest with a 'self-interest rightly understood'. In addition, associations cultivate reciprocity and trust among individuals, enabling them to accomplish tasks together they could not manage alone".

The membership of a broad-based community organization is made up of a range of different secondary associations or mediating institutions, including churches, mosques, temples, synagogues, schools, unions and community organizations. These discrete associational forms represent civil society institutions which are intermediate between the private world of the family household and the wider public world. Understood in political and sociological terms, whilst they all may have an outward focus and public orientation, they are essentially private, civil society institutions with relatively limited power. The institution of a broad-based community organization can be understood in phenomenological and Arendtian terms as the actualization of plurality, whereby a diverse range of institutions within a given area agree to associate, to pay dues, to act in concert and to build relational power. For example, initiated in 1995 in East London, London Citizens, the largest 
broad-based community organization in the UK now numbers over two hundred member institutions across the whole of London.

The structure of London Citizens with member organizations, organized in four chapters, covering, north, east, south and west London, allows for different levels of democratic participation and engagement by members at a local, borough and city-wide level. Saul Alinsky, the founder of community organizing, understood that whilst on the surface the problems associated with poor communities were often presented in terms of needs and deficiencies, the underlying causes and how they were to be addressed was fundamentally to do with power. Alinsky's great insight was that in poor communities, institutions such as faith groups, unions and other community-based organizations could be brought together and harnessed to build a more powerful broad-based institution. In the process, radicalism and tradition could be combined in building diverse broad-based coalitions rooted in the lives, values and institutions of the poorest citizens (Ritchie, 2019)

In $\mathrm{CO}$, a great deal of emphasis is placed on teaching about power and the form of relational or associative power which is built when local institutions join together to form a broad-based community organization. In terms of the associative and dissociative conceptions of the political, mentioned earlier in relation to Arendt and Schmitt, respectively, the primary impulse and substantive operative mode of a broad-based community organization is that which accords to the Arendtian associative tradition. As a newly instituted political actor, committed to developing associative power for public action, there is the potential to generate antagonistic as well as agonistic relations. To be political therefore, means to take seriously the antagonistic dimension of the political but to also recognize its agonistic dimensions and the potentially positive aspects of certain forms of conflict (Mouffe, 2005).

As mentioned earlier, in giving ontological priority to antagonism, theorists like Chantal Mouffe and Ernesto Laclau, subscribe to the dissociative tradition of Carl Schmitt on the nature and constitution of the political. According to these theorists the political "we" is constituted by the "they", in other words the "constitutive outside" helps to form the identity of the "we". In contrast, Arendt gives ontological priority to plurality and to the constitution of the "we" from within rather than from without, manifest in the commitment of a plurality of actors joining together for a common political purpose. It is not that Arendt denies the need for antagonism in acting politically for social justice-her life and works testify to that. Rather, in prioritizing the constitutive "we" from within, Arendt emphasizes the autonomous nature of the political and the conception of power as the capacity to act in concert. In its understanding and teaching of power, $\mathrm{CO}$ accords most closely to this Arendtian perspective.

There are echoes of the associative/dissociative traditions in the wider literature on community development, in the distinction made between so-called consensus and conflict-based approaches. In this regard $\mathrm{CO}$, particularly within the Alinskyan tradition, is often labelled a conflictbased approach. The distinction between consensus and conflict-based approaches is, in my view, too simplistic. In reality, effective political engagement requires both the potential for consensus and conflict, with the power of an organization, understood in Arendtian terms as the ability of people to act in concert, largely determining the extent to which consensus and conflict-based approaches can be employed tactically and strategically. Such an understanding, however, raises the question about the relationship between "politics" and "the political" discussed earlier and the balance that can be achieved in $\mathrm{CO}$ between both engaging episodically in power politics in order to "win" and achieve success on issues, and the longer term and more enduring aim which is the development of the political in keeping a plural and diverse alliance of associations together in order to uphold the notion of building a common life through the practices of democratic politics (Bretherton, 2015). This is a difficult balancing act to achieve and beyond the successes on a range of issues including, in the case of London Citizens, affordable housing, resettlement of refugees and most notably, the real living wage, perhaps the greatest achievement is the fact that so many IAF broad-based community organizations, across a number of countries, have survived and flourished as political entities over many decades.

\section{Action}

In her analysis of political agency and collective action in On Revolution, Arendt focuses on the nature of the relationship between those who initiate action and those on whose behalf the action is initiated. Arendt distinguishes between pity and compassion, on the one hand, and solidarity on the other. She says,

It is out of pity that men 'are attracted to les hommes faibles' (weak men, italics mine) but it is out of solidarity that they establish deliberately, and as it were dispassionately, a community of interest with the oppressed and exploited...... solidarity though it may be aroused by suffering, is not guided by it, and it comprehends the strong no less the weak and poor (1990, p.88).

At the heart of Arendt's conceptualization of solidarity is the idea of diverse equals acting together in a community of mutual interest. In comprehending "the strong no less 
than the weak and poor", Arendt, I believe, draws attention to the importance of authoritative public actors, capable of inspiring public action through speech and deeds. This resonates with the so-called iron rule of organizing in the Industrial Areas Foundation, i.e. "never do for others what they can do for themselves". In other words, people through their participation in a broad-based community organization grow and develop as leaders through speaking and acting in the public realm.

According to Villa (2008), Arendt's theory of political action has a number of irreducible features, which, amongst other things, include a pervasive frailty that comes from constantly moving amongst a plurality of independent actors; and related to this a "boundlessness" that comes from the unpredictability of never really knowing what the consequences of public action will be. Thus, as well as being a doer, a public actor, Arendt maintains, is also a sufferer in that the actor often does not reach the goal that she originally envisaged. Indeed, due to its boundlessness and unpredictability, the futility of action is always a very real possibility. In considering the unpredictability of action, Totschnig (2019:189) asks the question "if an actor cannot know where her initiative will lead, what motivates and guides her in her doings?". Totschnig maintains that action must be guided by principles rather than goals. He says,

Because of its generality, a principle can be shared by a plurality of agents. Whoever you are, whatever your station, you can partake in the realization of justice, or charity, or honour. This is to say that only because it is guided by principles can action be in concert. To act with (or against) others means to be committed to the same (or conflicting) principles (p.196).

In $\mathrm{CO}$, the principles often referred to include social justice, dignity, democracy, recognition, and in the words of Alinsky (1989a:xiv) "a belief in people, a complete commitment to the belief that if people have the power, the opportunity to act, in the long run they will, most of the time, reach the right decisions". On the point about recognition, this is not recognition usually associated with identity politics but rather the recognition that comes from building sufficient power, alongside others, to claim a place as actors in public life and to be recognized in the public realm. Whilst the pressure to achieve goals and succeed in action is always there, not least to sustain the membership, momentum and funding of the organization, it is seen as vitally important to develop a core of leaders and member institutions who are committed to the underlying principles which guide the action undertaken.

Another point that Totschnig raises in relation to the unpredictability of action is the relationship between action and the reaction to it. He says, "To act is to act with or against other agents who will not simply yield to the initiative but rather react to it" (p.195). In this sense, the action can be understood as the sum of the responses it provokes with the prerogative resting with those who respond (Thiele, 2009). In relation to London Citizens, a good example of the unpredictability of action and the reaction to it was provided by the announcement of a "National Living Wage (NLW)" by the UK Conservative government in the 2015 budget. The announcement came as a surprise to many, not least the organizers and leaders within London Citizens who had driven the living wage campaign for over 15 years. At one level, it represented recognition and a significant victory in establishing a large increase in the legal wage floor and the rate previously set by the National Minimum Wage. At another level, it was a blatant co-option of the ideas and practices of London Citizens by the government. This caused a degree of confusion, referred to by the Resolution Foundation, as a "terminological muddle", obfuscating the difference between the lower government National Living Wage rate and the higher Real Living Wage (RLW) rate determined by the Living Wage Foundation, the independent body which had grown out of the campaign waged by London Citizens over so many years.

The notion that the "action is in the reaction" is an important refrain in IAF training and lies at the heart of Alinsky's rules of power tactics, elucidated in "Rules for Radicals: A Pragmatic Primer for Realistic Radicals" (1989b). Whilst Alinsky's provocative prose in which he often talked in irreverent and polarized terms often drew criticism from detractors, it can in itself be seen as a form of action designed to elicit a reaction, which could be turned to advantage. In a recent article, Fretz (2019) highlights Alinsky's irreverence, humour and comic vision as being fundamental to the way in which he crafted a philosophy and methods of community organizing that invited ordinary people into the democratic process. Understood in phenomenological and Arendtian terms, it highlights Alinsky's acute awareness that action "acts into a medium where every reaction becomes a chain reaction and where every process is the cause of new processes" (Arendt, 1998:190).

In relation to $\mathrm{CO}$, authentic public action must be grounded in an established relational culture and one of the primary methods for establishing such a culture is the oneto-one, or relational meeting. A one-to-one is essentially a private conversation aimed at establishing the potential for a public relationship and for actualizing public action. It is regarded as the fundamental building block of $\mathrm{CO}$ and is one of the core features of what it means to communicate meaningfully with another human being. In "Roots for Radicals", Chambers refers to it as the most radical thing taught by the IAF. He defines it as: 
An encounter that is face-to-face - one to one - for the purpose of exploring the development of a public relationship.... A solid relational meeting brings up stories that reveal people's deepest commitments and the experiences that give rise to them.... stories that open a window into the passions that animate people to act (Chambers, 2003:44).

Such an understanding resonates with Mills' (1970) correlation of "private troubles" and "public issues", the relational meeting providing the mechanism through which people's narratives and stories translate to action. In his analysis of Arendt's ontology of action, Thiele places the notions of story and narrative at the heart of Arendt's understanding of freedom and the meaning of action. Thiele (2009) says,

As political actors, we demonstrate our freedom by initiating stories that invite responses, just as our individualities are announced by births that launch the sagas of our lives. Political actors are not sovereign authors; they are characters in the midst of composition. In a democracy, this fact not only describes the nature of political action. It is meant to inform the self-understanding of citizens and statespeople.

Involvement in a broad-based community organization allows for alternative individual and collective narratives to be created. It is through action that public freedom is expressed and new narratives fomented. Whilst the actions undertaken may or may not be successful in achieving their goals, the meaning and interpretation of action, including the reaction to it, may change over time. In this way, the stories and narratives generated through action with others provide the basis for the constitution of individual and collective meaning.

\section{Appearance}

In Being and Time, Heidegger draws on a classical conception of phenomenon, whereby the phenomenon is understood as that which shows itself or that which reveals itself (Heidegger, 2010). According to Loidolt, Arendt politicizes this understanding from the notion of appearance for someone to worldly appearance for many. For Arendt therefore, "to be real means to appear; to be a self means to appear; to 'be of the world' means to fundamentally belong to the realm of appearance" (Loidolt, 2018:53). In this, Arendt, sets herself against a Platonist perspective which holds that the world of forms is the essential basis of reality and it is the task of the philosopher alone, in the light of these true forms, to rule over the conflicting opinions of citizens. According to Arendt, it was from Plato onwards that philosophy and politics "parted company" (Kohn, cited in Villa, 2000:121) and it was this, along with the perception of Heidegger as the archetypal lone philosopher, which contributed to her ambivalence of philosophy mentioned earlier.

In $\mathrm{CO}$, this sense of appearing is closely linked to the concepts of dignity and recognition, whereby it is through public action that citizens become visible on a public stage. Dignity and recognition can thus be understood in political and intersubjective terms as qualities of esteem and respect that appear between plural beings who act together in concert. A phenomenological understanding of how the actualization of plurality through public action helps to constitute "spaces of appearance" provides important insight into how dignity and recognition emerge through struggle. In her analysis of undocumented immigrants in the USA, Beltran draws on an Arendtian framework to examine how through public action, in response to living out their lives in the shadows, immigrants focused on issues of dignity and recognition, rather than simply economic concerns. In framing the undocumented as subjects of natality, rather than necessity (through the process of labour), Beltran argues that the 2006 immigration reform protests across the USA are best understood as a moment of initiation and an inaugural performance of the political. She says, "By taking to the streets and claiming space and rights, immigrants and their allies created relational spaces of freedom and common appearance where none existed before" (Beltran, 2009:597).

From an Arendtian perspective, there is a performative aspect to this which takes on added meaning and significance. Where action is understood as fragile and boundless, those that enter and perform in the public realm, are in Arendt's eyes, worthy to be considered of greatness. As she reminds us in The Human Condition, "Greatness can lie only in the performance itself and neither in its motivation nor its achievement" (1998:206). In this, Arendt sidelines the instrumental priority often afforded to action in terms of immediate results, instead drawing attention to the ontological dimension of action in the way that subjectivity is produced and transformed (Beltran, 2009). As an aside, Boyte, a strong advocate of broad-based community organizing, takes issue with Beltran's Arendtian interpretation, claiming that in focusing on "the performance itself", Beltran "..sunders the roots of public actions from the organizing work that led up to them" (Boyte, 2010, p. 871). Whilst Boyte makes a valid point, based in the distinction he draws between organizing and mobilizing, it need not detract from a phenomenological understanding about the importance and significance of appearance in $\mathrm{CO}$. To this end appearance in the sense of being visible and being recognized publicly represents a central strategic aim and tactical ploy of $\mathrm{CO}$. 
One important way that visibility and recognition are achieved in $\mathrm{CO}$ is through large-scale assemblies. The assembly provides both a means for the member institutions to appear to themselves and thus substantiate their ability to turn people out and act in concert, but also to speak to power and to do public business. Highlighting the role of the assembly as a display of "people power" Ritchie (2019) documents a London Citizens assembly in 2016 , attended by over six thousand people in the run-up to the 2016 London mayoral election. Ritchie (2019:29) says:

The focus on "people power" was on display at the London Citizens' Assembly. Its power comes from its ability to unite citizens from a wide range of backgrounds in long-term public relationships. The six thousand citizens at the mayoral assembly were not isolated individuals. All were members of one or another of the 210 institutions that make up the alliance. Most had been involved in the extensive process of listening and negotiating that shaped London Citizens' specific proposals - in this case on affordable housing, the living wage, and safe passage for refugees.

In a similar vein, Luke Bretherton in his analysis of London Citizens, speaks of the spatial dimensions, both geographic and symbolic, of democratic citizenship and the importance of finding ways of reconstituting a place-based politics through which citizens can learn how to appear, participate and perform in public space. Of broad-based community organizing, Bretherton (2015:156) says:

This work can be seen in how it: (1) respatializes and renders visible an institutional and physical political and civic life within its public performances; and (2) trains people in how to conduct public relationships within particular political terrains.

From a phenomenological perspective, "appearance" constitutes an important aspect of what it means to be political. $\mathrm{CO}$ is based upon an understanding that for those who lack power, being visible and being recognized are central issues in themselves. To appear means to build sufficient power with others to claim a public space and to be recognized as legitimate public actors by allies and potential adversaries alike.

\section{Authenticity}

Authenticity occupies a central place in existential thought, albeit there are many different interpretations of the meaning of authentic existence. This includes, amongst other things, making meaning of one's life out of a reality which is meaningless (Sartre, 1992), being in touch with one's inner self (Kierkegaard, 1985), and facing up to one's death and the anxiety this provokes (Heidegger, 2010). It is in public being-together that Arendt believes authenticity is grounded. Unlike Heidegger who saw "the they" (das Man), especially in public being-together, as absorbing the "who" of everydayness, Arendt maintained that is in acting alongside others that the "who" of self-hood is disclosed. This relates to the point made earlier about Arendt's insistence on the individual finding meaning through action. However, as Loidolt (2018) points out in relation to authentic and inauthentic realizations of the "we", it is not just about the activity and its visibility, but also how it is carried out. Thus, according to Arendt:

Power is actualized only where word and deed have not parted company, where words are not empty and deeds not brutal, where words are not used to veil intentions but to disclose realities, and deeds are not used to violate and destroy but to establish relations and create new realities (Arendt, 1998:200).

In the context of this article and the analysis of $\mathrm{CO}$, authenticity can be understood in terms of a tension and struggle, individually and collectively with others, to enact and give expression to values of social justice and democracy. In reflecting on the nature of authentic action for social justice, Edward Chambers, who succeeded Alinsky as Director of IAF in 1972, talks about the tension between "the world as it is" and "world as it should be". He says:

......it is the fate of human beings to exist in-between the world as it is and the world as it should be.

Reflective people of conscience are constantly and painfully aware of the gap between our so-called values and the facts of life in the everyday world within which we operate..... The tension between the two worlds is the root of radical action for justice and democracy (Chambers, 2003:29).

Similarly, in a recent article on faith-based community organizations and how they contribute to progressive social change, Delahanty (2020) talks about the tension that progressive religious people often feel between the values and moral convictions they proclaim and the struggle to publicly validate such commitments in concert with others. Referring to this as an "authenticity crisis" Delahanty highlights ways in which participation in a faith-based community organization can create a sense of personal moral authenticity through engagement in collective political action. He says:

Personal moral authenticity refers to the ambition to develop, enact, and perform a moral identity that is true to an enduring internal self, and to validate that identity through interaction with others. It is 
simultaneously an individualized project that locates agency within the self and a profoundly social undertaking that depends on interactions with others for its validation (Delahanty, 2020:1230).

The role of civil society is critical in providing the basis for people to develop a strong sense of an authentic self through a social commitment to collective action. As "political" problems are increasingly framed within the social economy of necessity (Kirwan, 2013), Arendt's preoccupation with active citizenship and with the autonomy of the political is prescient, given the increasing likelihood to find ourselves relegated to the status of clients or consumers of various social services offered by the state (Villa, 2008). Furthermore, with the advance of neoliberalism in recent decades, critiques of governmentality have drawn attention to ways in which "community" has increasingly been co-opted by government (Davies, 2007; Rose, 1999). For example, I have previously highlighted how, in the context of the UK, narratives of "partnership" and the "Big Society" have had a depoliticizing effect and impact upon the practices of third sector organizations, brought increasingly under the auspices of state managerialism and commissioning processes (Bunyan, 2013). Against this background, a phenomenological perspective which focuses upon the meaning, significance and authenticity of the political, reminds us of the importance of developing and sustaining agonistic and politicized models of community engagement.

\section{Conclusion}

The question of what it means to be political lies at the heart of much of Hannah Arendt's thinking. Starting from the human condition of plurality, she develops her understanding of the distinctive characteristics of political beingin-the-world (Yar, 2000), presented here as best understood from an existentialist phenomenological perspective and including the four "A"s of association, action, appearance and authenticity.

Community organizing provides an effective means for people to be political and it is through the human phenomena of associating, acting, appearing and struggling to be authentic, that politicalness, or the quality of being political is given expression. The joining together of secondary associations into a broad-based community organization allows for the possibility of a positive form of associative or relational power to be created, as people in their diversity and plurality, act together in concert for a common good. To be authentically political means to embrace the human condition of plurality and to commit to its actualization in solidarity with others. Arendt's insight into the nature of the political and the expression this finds in the example and practice of community organizing reminds us of the significance of the political in shaping individual self-hood and expressing collective public freedom.

\section{Declarations}

Conflict of interest The author declares that he has no conflict of interest.

Open Access This article is licensed under a Creative Commons Attribution 4.0 International License, which permits use, sharing, adaptation, distribution and reproduction in any medium or format, as long as you give appropriate credit to the original author(s) and the source, provide a link to the Creative Commons licence, and indicate if changes were made. The images or other third party material in this article are included in the article's Creative Commons licence, unless indicated otherwise in a credit line to the material. If material is not included in the article's Creative Commons licence and your intended use is not permitted by statutory regulation or exceeds the permitted use, you will need to obtain permission directly from the copyright holder. To view a copy of this licence, visit http://creativecommons. org/licenses/by/4.0/.

\section{References}

Alinsky, S. (1989a). Reveille for radicals. Vintage Books. Alinsky, S. (1989b). Rules for radicals. Vintage Books.

Allen, A. (2002). Power, subjectivity and agency: between arendt and foucault. International Journal of Philosophical Studies, 10(2), 131-149.

Arendt, H. (1972). On violence. Crises in the Republic (pp. 134-155). Harcourt.

Arendt, H. (1998). The Human Condition (2nd ed.). The University of Chicago Press.

Arendt, H. (1990). On Revolution. Penguin Books Ltd.

Beck, D., \& Purcell, R. (2013). International Community Organizing: Taking Power. Policy Press.

Beltran, C. (2009). Going public: Hannah arendt, immigrant action, and the space of appearance. Political Theory, 37(5), 596-622.

Bernstein, R. (2018). Why Read Hannah Arendt Today. Polity Press.

Boyte, H. C. (2010). a commonwealth of freedom: response to beltran. Political Theory, 38(6), 870-876.

Bretherton, L. (2015). Resurrecting democracy: faith. Cambridge University Press, Cambridge.

Bunyan, P. (2010). Broad-based organizing in the UK: Reasserting the centrality of political activity in community development. Community Development Journal, 45(1), 111-127.

Bunyan, P. (2013). Partnership, the big society and community organizing: Between romanticizing, problematizing and politicizing community. Community Development Journal, 48(1), 119-133.

Canovan, M. (1992). Hannah arendt: A reinterpretation of her political thought. Cambridge University Press.

Chambers, E. (2003). Roots for radicals. The Continuum International Publishing Group Ltd.

Davies, J. S. (2007). The limit of partnership: An exit-action strategy for local democratic inclusion. Political Studies, 55(4), 779-800.

DeFilippis, J., Fisher, R., \& Shragge, E. (2010). Contesting community: The limits and potential of local organizing. Rutgers University Press. 
Delahanty, J. (2020). Becoming "People of Faith:" personal moral authenticity in the cultural practices of a faith-based social justice movement. Sociological Forum. https://doi.org/10.1111/ socf. 12645

Dolan, F. M. (2000). Arendt on Philosophy and Politics. In Dana Villa \& Cambridge University (Eds.), The Cambridge Companion to Hannah Arendt (pp. 261-276). Cambridge: Press.

Fisher, R., \& Dimberg, K. (2016). The community organisers programme in England. Journal of Community Practice, 24(1), 94-108.

Fisher, R., \& Kling, J. (1994). Community organization and new social movement theory. Journal of Progressive Human Services, 5(2), 5-23.

Fretz, E. (2019). The Comic Vision of Saul Alinsky's Community Organizing Tradition. American Studies Journal, https://doi.org/ $10.18422 / 66-05$

Fry, K. (2009). Arendt: A guide for the perplexed. Continuum Press.

Heidegger, M. (2010). Being and time (Translation by Joan Stambaugh). SUNY Press.

Hinchman, L. P., \& Hinchman, S. K. (1984). In heidegger's shadow: hannah arendt's phenomenological humanism. The Review of Politics, 46(2), 183-211.

Kierkegaard, S. (1985). Fear and trembling. Penguin.

Kirwan, S. (2013). On the 'inoperative community' and social authority: A nancean response to the politics of loss. Journal of Political Power, 6(1), 69-86.

Laclau, E., \& Mouffe, C. (2001). Hegemony and socialist strategy: Towards a radical democratic politics (2nd ed.). Verso.

Loidolt, S. (2018). Phenomenology of plurality: Hannah arendt on political intersubjectivity. Routledge.

Marchart, O. (2007). Post-foundational political thought: Political difference in nancy. Badiou and Laclau, Edinburgh University Press, Edinburgh.

Marchart, O. (2011). Democracy and minimal politics: The political difference and its consequences. The South Atlantic Quarterly, 11(4), 965-973.

May, D. (2018). The politics of friendship: Hannah arendt and the organizing of the industrial areas foundation. The Good Society, 27(1-2), 86-109.
Mills, C. W. (1970). The sociological imagination. Harmondsworth: Pelican.

Mouffe, C. (2005). On the political. Routledge.

Parekh, B. (1981). Hannah arendt and the search for a new political philosophy. Macmillan.

Passerin, M. (1994). The political philosophy of hannah arendt. Routledge.

Reynolds, J. (2006). Understanding existentialism. Acumen Publishing Ltd.

Ritchie, A. (2019). Inclusive populism: Creating citizens in the global age. University of Notre Dame Press.

Rose, N. (1999). Powers of freedom: Reframing political thought. Cambridge University Press.

Sartre, J. P. (1992). Being and nothingness. Simon and Schuster.

Thiele, L. P. (2009). The ontology of action: Arendt and the role of narrative, theory \& event 12(4). Project Muse. https://doi.org/10. $1353 /$ tae. 0.0101

Totschnig, W. (2019). Unpredictable yet guided: Arendt on principled action. The Journal of the British Society for Phenomenology, 50(3), 189-207.

Villa, D. (Editor) (2000). Chapter by Jerome Kohn entitled 'Freedom: the priority of the political', pp. 113-129, in The Cambridge Companion to Hannah Arendt, Edited by Dana Villa, Cambridge, Cambridge University Press.

Villa, D. (2008). Public freedom. Princeton University Press.

Warren, M. (2001). Democracy and association. Princeton University Press.

Willis, P. (2001). The "Things Themselves" in phenomenology. Indo-Pacific Journal of Phenomenology, 1(1), 1-12.

Yar, M. (2000). Arendt's heideggerianism: Contours of a 'Postmetaphysical' political theory? Journal for Cultural Research, $4(1), 18-39$.

Publisher's Note Springer Nature remains neutral with regard to jurisdictional claims in published maps and institutional affiliations. 